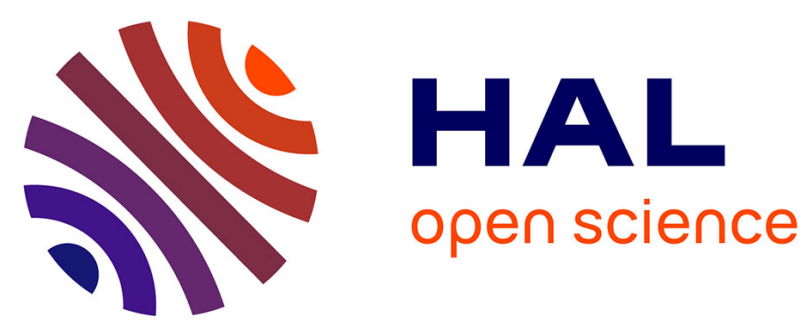

\title{
Common Features on Damage Mechanisms Identified on Various Metal and Ceramic on Polyethylene Articulating Surfaces of Total Hip Prostheses
}

Denis Najjar, François Hennebelle, Alain Iost, H. Migaud

\section{- To cite this version:}

Denis Najjar, François Hennebelle, Alain Iost, H. Migaud. Common Features on Damage Mechanisms Identified on Various Metal and Ceramic on Polyethylene Articulating Surfaces of Total Hip Prostheses. Materials Science Forum, 2007, 539-543, pp.629-634. 10.4028/www.scientific.net/MSF.539-543.629 . hal-01195690

\author{
HAL Id: hal-01195690 \\ https://hal.science/hal-01195690
}

Submitted on 21 Jun 2017

HAL is a multi-disciplinary open access archive for the deposit and dissemination of scientific research documents, whether they are published or not. The documents may come from teaching and research institutions in France or abroad, or from public or private research centers.
L'archive ouverte pluridisciplinaire HAL, est destinée au dépôt et à la diffusion de documents scientifiques de niveau recherche, publiés ou non, émanant des établissements d'enseignement et de recherche français ou étrangers, des laboratoires publics ou privés. 


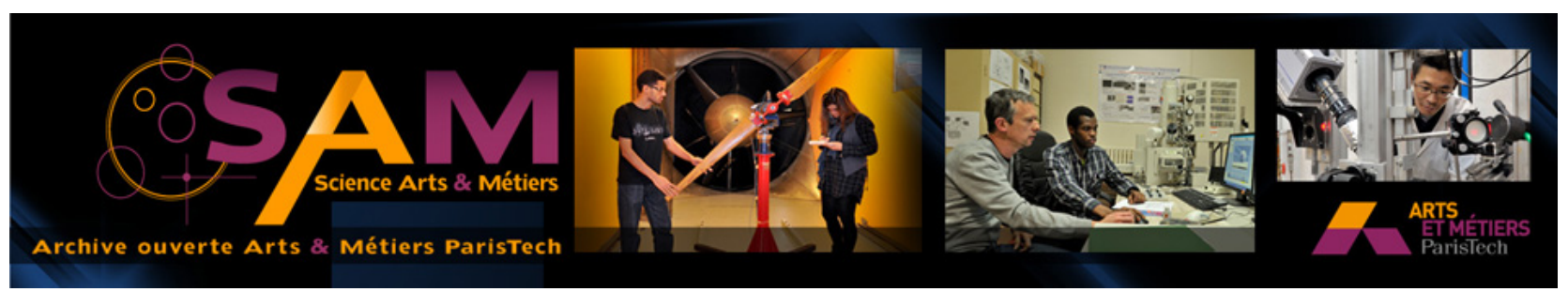

\section{Science Arts \& Métiers (SAM)}

is an open access repository that collects the work of Arts et Métiers ParisTech researchers and makes it freely available over the web where possible.

This is an author-deposited version published in: http://sam.ensam.eu

Handle ID: .http://hdl.handle.net/10985/9945

\section{To cite this version :}

Denis NAJJAR, François HENNEBELLE, Alain IOST, Henri MIGAUD - Common Features on Damage Mechanisms Identified on Various Metal and Ceramic on Polyethylene Articulating Surfaces of Total Hip Prostheses - Materials Science Forum - Vol. 539-543, p.629-634 - 2007 


\title{
Common features on damage mechanisms identified on various metal and ceramic on polyethylene articulating surfaces of total hip prostheses
}

\author{
D. Najjar ${ }^{1}$, F. Hennebelle ${ }^{2}$, A. lost $^{1}, \mathrm{H}$. Migaud $^{3}$ \\ ${ }^{1}$ Laboratoire de Métallurgie Physique et Génie des Matériaux, UMR CNRS 8517, Equipe \\ Caractérisation et Propriétés des Périsurfaces, ENSAM, 8 Boulevard Louis XIV, 59046 Lille Cedex, \\ France \\ ${ }^{2}$ Laboratoire de Métrologie et Mathématiques Appliquées, ENSAM, 8 Boulevard Louis XIV, 59046 \\ Lille Cedex, France \\ ${ }^{3}$ Centre Hospitalier Régional Universitaire, Hôpital Roger Salengro, Service d'Orthopédie C, 2 \\ Avenue Oscar Lambret, 59037 Lille Cedex, France \\ denis.najjar@lille.ensam.fr; francois.hennebelle@lille.ensam.fr; alain.iost@lille.ensam.fr; h- \\ migaud@chru-lille.fr
}

Keywords: Total hip prostheses, articulating surfaces, wear mechanisms, Ultra High Molecular Weight Polyethylene.

\begin{abstract}
This paper presents a methodology for assessing the in-vivo degradation mechanisms of articular components of total hip replacement (THR) prostheses of Charnley type. The experimental procedure revealed that common features can be observed even if the clinical cases under investigation were quite different with regard to the demographic data. It particularly emphasises the detrimental effects of foreign bodies on the damage of the articulating surfaces. These foreign bodies can migrate into the joint space before embedding definitely into the Ultra High Molecular Weight Polyethylene (UHMWPE) acetabular cup surface where they further participate to a third body wear mechanism accelerated by a progressive increase of the femoral head roughness.

Our experimental results underline, from a practical point of view, the need for careful manufacturing and clinical handling of porous surfaces, advocate for a systematic assessment of retrieved components, particularly when changed because of unexplained wear, and make questionable the clinical use of multifilament trochanteric cables.
\end{abstract}

\section{Introduction}

Since forty years, the most implanted THR prostheses are of Charnley type. These prostheses consist of an hard metallic or ceramic femoral head articulating against an UHMWPE acetabular cup. Most of the recent works on the long-term performance of these prostheses lead to the conclusion that one of the main limiting factor is the biological response of the body due to the accumulation of UHMWPE wear debris in the peri-prosthetic tissues [1-3]. As a consequence, the reduction of the UHMWPE wear debris and a better understanding of in-vivo wear mechanisms are of paramount importance with a view to improving the long-term clinical performance of THR prostheses; particularly for young patients for which both life expectancy and activity level are generally higher than those of old patients.

The aim of this paper is to present a methodology for assessing the in-vivo degradation of articular components of THR prostheses. Applied on four retrieved THR prostheses, this methodology combines a visual inspection with a macroscopic characterisation of the geometrical modifications of the acetabular cups of the damage and a microscopic characterisation of articulating surfaces. 


\section{Experimental Procedure}

General information on the retrieved components. For all retrieved THR prostheses, the studied articulating components consist of a $28 \mathrm{~mm}$ diameter femoral head and a UHMWPE acetabular cup inserted in a Harris-Galante Mark I metallic shell fixed with screws. Demographic data related to the patients are summarised in Table 1.

\begin{tabular}{|c|c|c|c|c|c|c|c|}
\hline $\begin{array}{c}\text { Clinical } \\
\text { Case }\end{array}$ & $\begin{array}{c}\text { Age at prosthetic } \\
\text { implantation } \\
\text { (years)/Gender }\end{array}$ & $\begin{array}{c}\text { Weight } \\
\text { /Height }\end{array}$ & $\begin{array}{c}\text { Level of } \\
\text { activity }\end{array}$ & $\begin{array}{c}\text { Primary } \\
\text { Diagnosis }\end{array}$ & $\begin{array}{c}\text { Revision } \\
\text { Diagnosis }\end{array}$ & $\begin{array}{c}\text { Femoral } \\
\text { head } \\
\text { material }\end{array}$ & $\begin{array}{c}\text { Follow-up to } \\
\text { retrieval } \\
\text { (years) }\end{array}$ \\
\hline A & $\begin{array}{c}17 \mathrm{y} \\
\mathrm{F}\end{array}$ & $\begin{array}{c}60 \mathrm{~kg} \\
1 \mathrm{~m} 60\end{array}$ & $\begin{array}{c}\text { Medical } \\
\text { assistant }\end{array}$ & $\begin{array}{c}\text { Avascular } \\
\text { necrosis of } \\
\text { femoral head }\end{array}$ & $\begin{array}{c}\text { Excessive wear } \\
\text { and osteolysis }\end{array}$ & Zirconia & 8.25 \\
\hline $\mathrm{B}$ & $56 \mathrm{y}$ & $70 \mathrm{~kg}$ & $\begin{array}{c}\text { House } \\
\text { wife }\end{array}$ & $\begin{array}{c}\text { Osteoarthritis } \\
\text { / Hip } \\
\text { dysplasia }\end{array}$ & $\begin{array}{c}\text { Trochanteric } \\
\text { non-union and } \\
\text { cable breakage }\end{array}$ & stainless steel & 3.5 \\
\hline C & $55 \mathrm{~m}$ & $60 \mathrm{~kg}$ & $\begin{array}{c}\text { Firm } \\
\text { Fanager }\end{array}$ & $\begin{array}{c}\text { Primary } \\
\text { osteoarthritis }\end{array}$ & $\begin{array}{c}\text { Femoral } \\
\text { osteolysis }\end{array}$ & TA6V & 4.5 \\
\hline D & $36 \mathrm{~m}$ F & $52 \mathrm{~kg}$ & $\begin{array}{c}\text { Active } \\
\text { Fouse } \\
\text { wife }\end{array}$ & $\begin{array}{c}\text { Primary } \\
\text { osteoarthritis }\end{array}$ & $\begin{array}{c}\text { Femoral and } \\
\text { acetabular } \\
\text { osteolysis }\end{array}$ & CoCrMo & 6 \\
\hline
\end{tabular}

Table 1: Main demographic data

Whatever the diagnosis of revision (wear, osteolysis or broken multicable filament), it must be pointed out that polyethylene debris had been detected by histological analyses on periprosthetic tissues but that no loosening had occurred during lifetime. The four THR prostheses considered in this study were mainly retained because of the visual detection of metallic fibbers embedded in the UHMWPE acetabular cups. Fig. 1 presents the retrieved articular components related to clinical case A and shows the presence of such a metallic fibber of millimetre size embedded into the surface of the UHMWPE acetabular cup but detected only after retrieval. Note also the adherent metallic deposit on the ceramic femoral head due to the friction of this counterface with the embedded fibber.

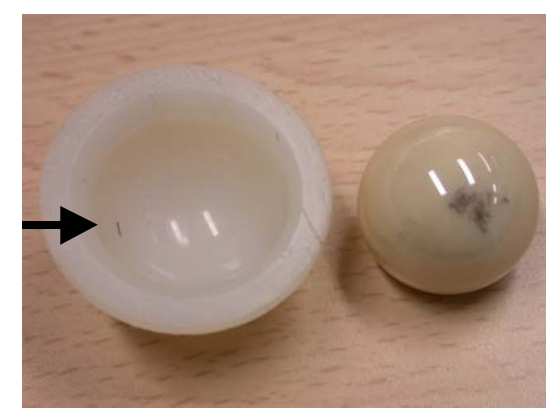

Fig. 1: Retrieved components related to clinical case A. The fibber is marked by a black arrow.

Experimental observations and measurements. The macroscopic characterisation of the geometrical modifications of the acetabular cups was performed using a co-ordinate measuring machine. The protocol consisted in defining a reference frame in which are recorded deviations between points located on the internal surface of the acetabular cups and target points located on the theoretical surface of an hemisphere of $28 \mathrm{~mm}$ diameter. The measurements were carried out in twelve parallel planes with a $1 \mathrm{~mm}$ depth interval. In each plane, thirty six equally spaced angular points were recorded in the perpendicular direction to the internal surface. In each direction, the deviation $e_{i}$ was estimated using the following definition :

$e_{i}=R o-\left(X_{i}^{2}+Y_{i}^{2}+Z_{i}^{2}\right)^{1 / 2}$ 
in which $R_{o}(=14 \mathrm{~mm})$ represents the theoretical radius and $X_{i}, Y_{i}, Z_{i}$ the co-ordinates of the recorded point on the internal surface of the acetabular cup.

The microscopic characterisation of the damage of articulating surfaces was performed by means of an optical microscope combined to visual inspection. As far as the femoral head were concerned, these qualitative observations were combined to quantitative roughness measurements by means of a 3D tactile profilometer having a $2 \mu \mathrm{m}$ stylus tip radius and using a $2 \mathrm{mg}$ stylus force. For each analysed area of the femoral heads, 200 scanning traces were recorded with a $3 \mu \mathrm{m}$ spacing interval. These measurements were performed at a scan rate of $100 \mu \mathrm{m} / \mathrm{s}$ with a scan length of $600 \mu \mathrm{m}$ and a sampling rate of $100 \mathrm{~Hz}$. A numerical treatment has been then computed to calculate, for each analysed area, the mean of the average arithmetic roughness $R_{a}$ of the 200 recorded scanning traces.

\section{Results and Discussion}

Damage analysis of the UHMWPE acetabular inserts. Whatever the retrieved acetabular cup analysed, the damage of the retrieved consists of dimensional changes at a macroscopic scale associated with degradation of surface topography at a microscopic scale. These retrieved acetabular cups exhibit two distinct areas that are symmetrically located. A first region is characterised by large deviations at a macroscopic scale and has a highly polished smooth appearance at naked-eye. Little scratches are detected by optical microscopic observations in this region denoted HW contrary to the other one denoted LW; region for which the recorded deviations are small (Fig. 2).

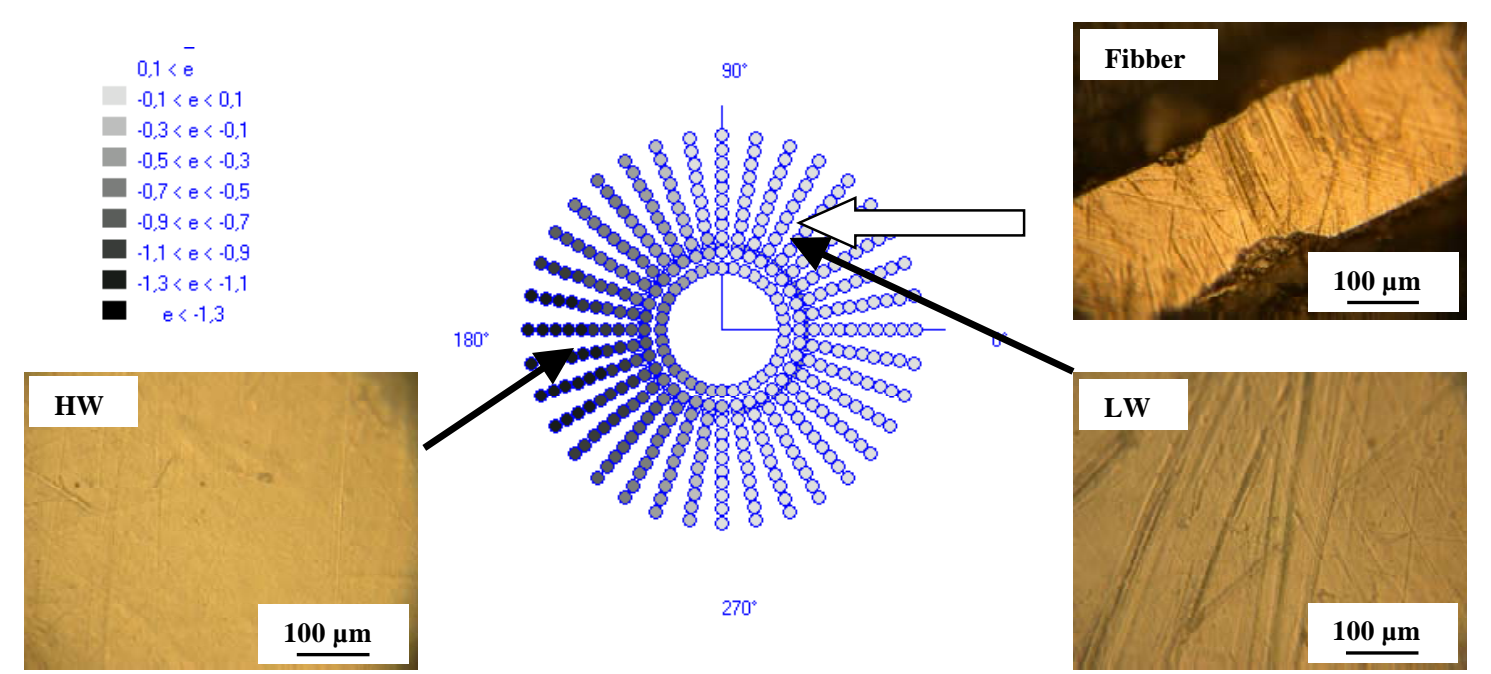

Fig. 2: Example of stereographic projection of deviations (e in $\mathrm{mm}$ ) between points located on the internal surface of the retrieved acetabular cup and those located on a theoretical hemisphere of $14 \mathrm{~mm}$ radius (clinical case A). The white arrow indicates the location of the embedded fibber.

Similar observations were already reported by others authors both on retrieved UHMWPE cups of cemented Charnley prostheses and on cups tested with a hip simulator [4,5]. In these studies, the authors attributed the area having a highly polished smooth appearance to the bearing contact area where the femoral head penetrates in the UHMWPE acetabular cup. According to these authors, a fatigue-adhesion wear mechanism of the UHMWPE acetabular cup combined to creep are likely to operate in this first typical kind of region that they referred as a high-wear region. In the second typical kind of area, while only machining marks were detected in the case of acetabular cups tested with a hip simulator, rumpling and embedded particles of acrylic cement were also evident in the case of retrieved cemented cups. In this latter case, this area had a rougher appearance than the first one and it was referred as a low-wear region. Moreover, both the two areas showed pits and scratches that were thought to be caused by a third body wear mechanism due to the action of acrylic cement particles trapped between the articulating surfaces. 
In agreement with the conclusions of these authors, it can be concluded that the large deviations recorded in the area HW indicate the effective direction of loading and are the consequence of the femoral head penetration in the UHMWPE acetabular cup by the combination of creep and a fatigue/adhesion wear mechanism. The related values of the maximum linear penetration rates in the UHMWPE are summarised in Table 2 for the four studied clinical cases. Such values are consistent with the clinical penetration rates reported in the literature. While these clinical penetration rates exhibit a great variability, they are generally less than about 0.25 mm.year ${ }^{-1}$ and often correspond to an average of $0.1 \mathrm{~mm}_{\text {.year }}{ }^{-1}$ or less [4,6]. Moreover, substantial clinical evidence now accumulating indicates that long term survival of the implant is associated with penetration rates of less than 0.1 mm.year ${ }^{-1}$ while case requiring revision often exhibit penetration rates of about 0.2 mm.year ${ }^{-1}$ or higher [6].

\begin{tabular}{|c|c|c|c|}
\hline Clinical Case & Femoral head material & Follow-up to retrieval (years) & Linear penetration rates ( $\boldsymbol{\mu m}$ /year) \\
\hline A & Zirconia & 8.25 & 153 \\
\hline B & 316L & 3.5 & 174 \\
\hline C & TA6V & 4.5 & 96 \\
\hline D & CoCrMo & 6 & 253 \\
\hline
\end{tabular}

Table 2: Maximum linear penetration rates estimated from the recorded deviations and the implantation time of the THR prostheses

As far as the region LW is concerned, it is thought that the numerous scratches observed at the surface of the UHMWPE acetabular cups are the consequence of a third-body wear mechanism. Indeed, it is worth noting that some of the detected scratches exactly have the same shape and dimension as the metallic fibbers of millimetre size. Moreover, the surface of these metallic fibbers, always located in this region LW, are also severely scratched (Fig. 2).

Damage analysis of the femoral heads. Hard foreign bodies undoubtedly increases the rate of removal of polyethylene, but they might be also responsible for the degradation of the retrieved femoral heads [2,4,7]. The deleterious effect of the embedded foreign third bodies of large dimensions is also evident at the surface of all the retrieved femoral heads under investigation in this study. However, the present results show that the wear mechanism at the origin of the degradation of the initial surface finish depends on the nature of femoral head. Indeed, numerous scratches are detected at naked-eye at the surface of the femoral heads made in 316L and TA6V passive alloys. Microscopic observations of such scratches obtained by means of an optical microscope are shown in Fig. 3. These scratches covers approximately $25 \%$ of the total surface of the femoral head in the case of the 316L alloy and more than $60 \%$ in the case of the TA6V alloy that, among the biomaterials used for manufacturing the femoral heads of THR prostheses, is known to be the less resistant one to abrasive wear. In the case of the CoCrMo alloy, the initial bright finish is only altered on a small area covering less than $10 \%$ of the total surface of the femoral head. Observations by means of a Scanning Electron Microscope (SEM) reveal that this area consists of very small scratches combined with an adherent metallic deposit (Fig. 3). As for the zirconia femoral head, this latter can be identified as a titanium deposit by Energy Dispersive Analysis of $\mathrm{X}$ rays (EDAX); chemical element which is contained in the original chemical composition of the fibbermesh deposited on the Harris-Galante Mark I metallic shells but not in those of the femoral heads under consideration. In other words, these metallic deposits result from an adhesive wear mechanism due to the friction between the embedded metallic fibbers of large dimensions and the femoral heads. 

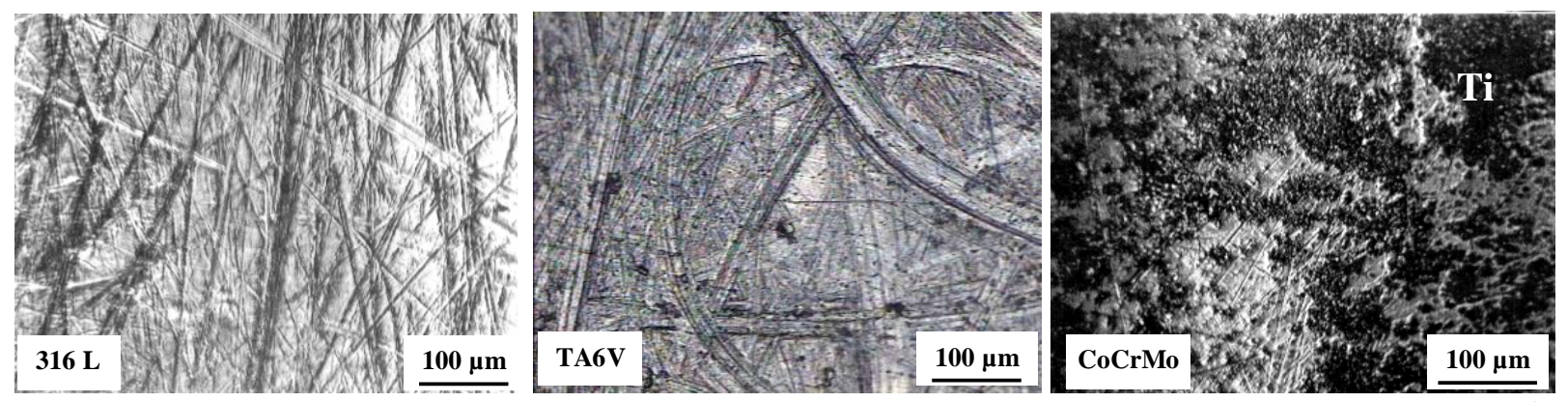

Fig. 3: Damage of the metallic femoral heads observed by means of an optical microscope for the 316L and TA6V femoral heads and by means of a SEM for the CoCrMo femoral head.

Whatever the wear mechanism, i.e. abrasive wear in the case of the 316L and TA6V alloys and mainly adhesive wear in the case of CoCrMo alloy and zirconia which are more resistant to abrasive wear, the degradation of the topography of the femoral heads leads to an increase of the effective roughness which has been shown to be a major factor in determining the wear of polyethylene and the long term performance of implants $[1,3,8,9]$. Indeed, whatever the femoral head, the experimental results reported in Table 3 show that the values of the average arithmetic roughness parameter recorded in the damaged areas are always significantly higher than those recorded in undamaged areas having a bright finish. Besides, these latter values are similar as those mentioned in the ISO 7206-2 standard which specifies the guidelines for new acetabular components of THR prostheses [10]. In agreement with others authors [4,6-9], it is also thought that, from a global point of view, the degradation of the initial surface finish by hard foreign bodies is a random phenomenon suspected to be a major factor responsible for the discrepancy existing in the literature between the average clinical and laboratory wear factors as well as the wide spread of results.

\begin{tabular}{|c|c|c|c|c|}
\hline Clinical Case & Femoral head & Damaged area & Undamaged area & ISO 7206-2 \\
\hline A & Zirconia & $0,07 \mu \mathrm{m}$ & $0.01 \mu \mathrm{m}$ & $<0.02 \mu \mathrm{m}$ \\
\hline B & $316 \mathrm{~L}$ & $0.16 \mu \mathrm{m}$ & $0.03 \mu \mathrm{m}$ & $<0.05 \mu \mathrm{m}$ \\
\hline C & TA6V & $0.24 \mu \mathrm{m}$ & $0.03 \mu \mathrm{m}$ & $<0.05 \mu \mathrm{m}$ \\
\hline D & CoCrMo & $0.10 \mu \mathrm{m}$ & $0.04 \mu \mathrm{m}$ & $<0.05 \mu \mathrm{m}$ \\
\hline
\end{tabular}

Table 3: Values of the average arithmetic roughness parameters recorded in damaged and undamaged areas of the studied femoral heads in comparison with those specified in the ISO 7206-2 standard.

Phenomenological generic scenario. All the experimental observations of this study enables to propose a phenomenological generic scenario for explaining the premature failures of Charnley total hip prostheses. During the implantation time of a THR prosthesis of Charnley type, a progressive penetration of the femoral head in the UHMWPE acetabular cup is supposed to occur in a first time by creep and fatigue/adhesion. This progressive penetration of the femoral head at the bearing contact region is concomitantly associated to an increase of the effective joint space (clearance) between the components. This increased clearance in the symmetrically located area can allow the random entrance of foreign bodies of millimetre into the joint space that can further participate to a third-body wear mechanism of the articulating surfaces. Such a detrimental influence of embedded hard foreign bodies on the wear of the articulating surfaces has been already reported in the literature; not only for pieces of and fibbers from metallic shells and trochanteric cable or wire as concerned in the present investigation but also for fragments of acrylic cement, metal beads from porous coating and particles of bone [2,4,11-14]. This damaging third body wear mechanism of articulating surfaces may produce an increase of both polyethylene and metallic debris with a production rate that can be dramatically accelerated by the degradation of the initial femoral head roughness by a wear mechanism depending on whether it is a metallic (mainly abrasive wear) or a ceramic femoral head (mainly adhesive wear). This abnormal and autocalytic increase of polyethylene and metallic debris leads to their accumulation in the peri-prosthetic tissues favouring the occurrence of the osteolytic reactions and, consequently, the premature failure of the prosthesis. 


\section{Conclusions}

The macroscopic and microscopic features related to the damage of the components observed in this investigation were very similar while the clinical cases were quite different with regard to the demographic data. This experimental fact is at the origin of the proposal of a phenomenological generic scenario that can explain the premature failures of Charnley total hip prostheses. This scenario particularly emphasises the deleterious role of hard foreign bodies that can randomly enter the interface between sliding components of either a metal or a ceramic on polymer bearing configuration.

From a practical point of view, the experimental results of this investigation make questionable the clinical use of multifilament cable for trochanteric fixation. Moreover, they underline the need for careful manufacturing and clinical handling of porous surfaces and they advocate for a systematic assessment of retrieved components. Finally, they demonstrate how important it is to impede hard abrasive particles access to the interface between articular components of a hip prosthesis.

\section{Acknowlegdments}

This study is a part of a project of the Fédération des Biomatériaux Nord- Pas de Calais cofunded by the French Government (FRT 15049/02Y0321) and Europeean Community (FEDER Obj 22003/4-4.1-N ${ }^{\circ}$ 118/3186). The authors would like to thank Dr. T. Coorevits for the helpful discussions and Mr. J.C. Vervisch for its technical assistance.

\section{References}

[1] C.M. MacNie, D.C Barton, E. Ingham, J.L. Tipper, J. Fischer, M.H. Stone. J. Mat. Sci.: Mat. Med. 11 (2000), p. 163.

[2] C.M. MacNie, D.C Barton, E. Ingham, J.L. Tipper, J. Fischer, M.H. Stone. J. Mat. Sci.: Mat. Med. 11 (2000), p. 569.

[3] J.L. Tipper, E. Ingham, J.L. Hailey, A.A. Besong, J. Fisher, B.M. Wroblewski, M.H. Stone. J. Mat. Sci.: Mat. Med. 11 (2000), p. 117.

[4] J.R. Atkinson, D. Dowson, G.H. Isaac, B.M. Wroblewski. Wear 104 (1985), p. 217.

[5] J.R. Cooper, D. Dowson, J. Fisher, B.M. Wroblewski. J. Mat. Sci. Mat. Med. 5 (1994), p. 52.

[6] D. Dowson D. Wear 190 (1995), p. 171.

[7] R.M. Hall, P. Siney, A. Unsworth, B.M. Wroblewski. Med. Eng. Phys. 8(1997), p. 711.

[8] D. Dowson, S. Taheri, N.C. Wallbridge. Wear 119 (1987), p. 277.

[9] T.D. Brown, K.J. Stewart, J.C. Nieman, D.R. Pedersen, J.J. Callaghan. J Biomechanical Engineering 124 (2002), p. 691.

[10] ISO 7206-2, Implants for surgery-Partial and total hip joint prostheses-Part2: Articulating surfaces made of metallic, ceramic and plastics materials, 1996.

[11] H.A. McKellop H, A. Sarmiento, C.P. Schwin, E. Ebramzadeh E. J Bone Joint Surg. (Am) 72 (1990), p. 512.

[12] S.S. Kelley, R.C. Johnston. Clin. Orthop. 285 (1992), p. 140.

[13] T.D. Owen, C.G. Moran, S.R. Smith, I.M. Pinder. J Bone Joint Surg. (Br) 76 (1994), p. 258.

[14] T.W. Bauer, J. Ming, A. D’Antonio, J.G. Morawa. J Bone Joint Surg. (Am) 78 (1996), p. 1244. 